\title{
The dancing front: dancing, morale, and the war effort in Britain during World War II
}

\author{
James Nott
}

\begin{tabular}{|c|c|}
\hline Date of deposit & 22082016 \\
\hline Document version & Author's accepted manuscript \\
\hline Access rights & $\begin{array}{l}\text { Copyright @ The Author } 2016 \text {. Published by Oxford University } \\
\text { Press. All rights reserved. This work is made available online in } \\
\text { accordance with the publisher's policies. This is the author } \\
\text { created, accepted version manuscript following peer review and } \\
\text { may differ slightly from the final published version. }\end{array}$ \\
\hline $\begin{array}{l}\text { Citation for } \\
\text { published version }\end{array}$ & $\begin{array}{l}\text { Nott, J. J. (2017). The dancing front: dancing, morale, and the } \\
\text { war effort in Britain during World War II. Journal of Social History, } \\
51(2), 387-406 .\end{array}$ \\
\hline $\begin{array}{l}\text { Link to published } \\
\text { version }\end{array}$ & https://doi.org/10.1093/jsh/shw112 \\
\hline
\end{tabular}

Full metadata for this item is available in St Andrews Research

Repository at: https://research-repository.st-andrews.ac.uk/

\section{St Andrews Research Repository}


Scheduled for publication in the Winter 2017 (51:2) issue of the Journal of

\section{Social History}

\section{The Dancing Front: Dancing, Morale and the War Effort in Britain during World War II}

\section{INTRODUCTION}

In December 1942 a correspondent for the Dancing Times described the dancing in the popular Liverpool dance hall the Grafton Rooms, nicknamed the "United Nations Ballroom of the North West":

Nightly on the spacious floor can be seen members of practically every nationality now serving under the banners of the United Nations...Here come the men of the merchant convoys, the lads in navy blue direct from escort duty, the well groomed airmen, the gallant boys in battle dress and - particularly during the past year - an ever increasing number of girls who have exchanged their ballroom frocks for the neat uniforms of the ATS, the WAAF and WRNS...[and] many girls... from the 'Factory Front. $^{1}$

Such scenes were not unique to Liverpool, however. Dancing was extraordinarily popular activity in wartime Britain, building on an already entrenched position at the heart of British social and cultural life. Tom Harrisson, for example, told a North American audience in a BBC broadcast in 1942 that dance halls were "booming exceptionally." He stated:

In a number of our big cities the biggest dance halls are packed completely to capacity, and the other evening in Glasgow I simply couldn't get in when I arrived at ten o'clock hoping to see the local finals 
of a Jitterbug competition. Hundreds were being turned away from the doors. $^{2}$

That year leading dance hall chain Mecca estimated that in one large provincial hall they ran, average attendance was 1000 per session, for eight four-hour sessions per week, with a total weekly attendance of 8000 . If this was replicated in the 500 dance halls across Britain we can presume weekly attendances of four million - double that estimated in $1938 .{ }^{3}$ Dancing had never been more popular.

This article, which discusses social dancing in Britain during the Second World War, is oriented towards questions of morale; the 'myth of the Blitz'; and the evolution of attitudes towards popular culture. It looks at how the unofficial efforts of dance hall owners dovetailed with official government efforts to raise morale; how such efforts shared in national myth making, creating a host of images and examples of philanthropy and bravery vital to patriotic propaganda. It also examines how the dance hall industry successfully navigated the challenges of wartime in order to alter perceptions about dancing and secure both its immediate and long-term future.

Despite performing important wartime functions, social dancing during the conflict has received little detailed attention from historians. Where it has been studied, the emphasis has been placed on its role in episodes of racially motivated conflict, primarily between American GIs. ${ }^{4}$ This article will thus provide the first detailed examination of dancing's wider wartime role. Moreover, it speaks to several key aspects of the historiography of the Second World War and of twentieth century British popular culture. First, it provides new evidence for the use of recreation and leisure as a strategy for boosting morale during the war. As Robert Mackay has noted, 
there were several ways in which the British government sought to maintain and extend morale. ${ }^{5}$ In addition to dealing with the necessities of everyday life, he points to a parallel strategy of using recreation and leisure to generate a sense of "popular well being." To date, there has been detailed examination of numerous types of wartime leisure and recreation used in this way, ${ }^{6}$ this, however, is the first examination of the use of social dancing.

Second, this article allows us to further examine the effectiveness of the Ministry of Information and its propaganda campaigns. Several studies, notably that of Ian McLaine, highlight the often sluggish response of the government to utilising all avenues available to it, itself a reflection of a lack of understanding and appreciation of the mood of the British public from the elites in the Ministry of Information and government. ${ }^{7}$ This article will add further evidence to the view that it was not until the appointment of Brendan Bracken at the MoI in 1941 that that institution became truly effective. Moreover, the example of the utilisation of dancing shows the extent to which civic society responded to Britain's war effort, and in particular how the initiative for many propaganda and morale-raising campaigns came not from the state, but from private individuals, businesses and communities themselves.

Related to this, the study of dancing and dance halls allow us to further ponder the nature of wartime propaganda and to examine the effects of the war on the British population. Despite differences of opinion on the state of morale, most historians agree that a powerful 'myth of the Blitz' was created both at the time and subsequently. ${ }^{8}$ In order to promote idealized ways of behaving, the virtues of stoicism, patriotism and sacrifice were promoted by the government and by numerous national institutions. The role of social dancing and dance halls in creating and 
spreading such national myths will be explored here for the first time. The dance halls' various campaigns to exalt ordinary men and women working in civil defence will also show that the concept of the 'People's War' had widespread popular currency, and was not just the product of officials in the Ministry of Information and Whitehall.

Finally, this article allows us to consider changing perceptions towards popular culture during the wartime, and the role of the owners of leisure facilities in trying to influence this perception. Prior to 1939 , the state and cultural and moral critics regarded aspects of popular culture with particular suspicion. ${ }^{9}$ The war, however, was to see a partial reversal of opinions. As James Chapman and Robert Murphy have shown for cinema, the state recognised popular culture's huge propaganda potential and, moreover, regarded its 'escapist' functions more positively too. ${ }^{10}$ Reluctantly, a similar process of grudging acceptance towards entertainment took place at the BBC. ${ }^{11}$ Dancing's reputation underwent a comparable transformation, though not without difficulties. It, too, was regarded negatively by a host of critics from the 1920s onwards. For racial and moral reasons, dancing rapidly attained a poor reputation and dance halls were regarded as 'suspect' venues, particularly by magistrates and judges. ${ }^{12}$ As with cinema, the war offered new challenges and opportunities to its reputation, and dance hall owner's strove to alter pre-war perceptions. This article thus offers fresh insight into changing perceptions of popular culture from the state and other official bodies during wartime.

\section{DANCING AND THE BLITZ}


This section has three key aims. First, it will establish government approaches to morale during the war, focusing particularly on policy towards entertainment venues. It adds further evidence to historical scholarship arguing that both the government and the MoI were out of touch with the civilian population, and that many of their efforts were heavy handed and ineffectual. Second, this section will extend our understanding of the role of leisure and popular culture on the Home Front, by pointing to the key role that dancing had in maintaining morale during the Blitz. It will also demonstrate that, from the very start of the war, the dance industry mobilised an effective strategy to try to reverse perceptions of social dancing and show it as vital to the war effort.

The importance of dancing to the morale of the civilian population was not appreciated by the government when war broke out. From the conflict's start, the government made attempts to monitor and measure the morale of the British population, but not always with great success or understanding, as Ian McLaine's, study of the Ministry of Information has noted. ${ }^{13}$ Through a process of trial, error and recrimination, however, the government's attitude evolved in such a way as to make it more open to less conventional means of raising morale.

At first, the power of popular entertainment to motivate and comfort was not fully understood, particularly in regards to dancing and dance halls. Yet the government did have a clear policy on how cinema and radio would be used during the war. Recognising the vast potential of these new mass media forms, the government moved swiftly to take control of them under the guidance of the Ministry of Information. The MoI advised that the BBC was to broadcast as much popular entertainment as possible in order to maintain morale, and the film industry, whilst 
eventually coming to focus on a new social realism, was not to neglect popular entertainment as a form of morale boosting either. Indeed, the 'wartime wedding' between commercial and documentary film styles sponsored by the MoI Films Division under Jack Beddington was as much a recognition of the power of popular culture to motivate as it was a recognition of the power of the documentary movement. Both of these policies, however, only emerged after disastrous early starts and a heavy-handed approach to controlling the new media.

With dancing, the greatest rival to cinema and radio in terms of popular entertainment, the situation was even more difficult, as there was no specific policy towards this activity at the outset of the war. Indicative of the lack of appreciation of how deeply embedded dancing was in the social and cultural life of the vast majority of the population by 1939 , the establishment elites at MoI initially neglected it. Writing in November 1939, Tom Harrisson of Mass Observation complained that whilst 'jazz' (by which he meant all popular music and its associated dances) “can undoubtedly be used as a major influence on morale" the MoI was failing to utilise it. This he put down the reactionary attitudes of the ministry: "One could not expect it," he wrote, "in an organisation whose conception is pre-scientific and almost preindustrial. Jazz therefore remains the biggest, unorganised channel of propaganda which exists."14

The situation elsewhere in the government was scarcely more enlightened, at least during the early stages of the war under the Chamberlain administration. At this point, the importance of dancing to civilian morale was only brought to the attention of the government through reaction to its early entertainment policy. This reaction was spearheaded by a dance industry keen to protect its interests. At the outbreak of the 
war all places of public entertainment were closed down by the authorities in anticipation of widespread bombing and fear of mass casualties. A campaign was soon launched to have this restriction reversed. As early as September 7, 1939, Tom Harrisson complained: "Bad for morale has been closing of all places of entertainment - complete non-realisation of mass action." 15 The press also joined in the condemnation. An editorial in The Spectator commented: "it is as clear as can be that such a ban on entertainment could not possibly remain general without an incalculable loss to the good spirits and morale of the nation." 16

The government's ineptitude in handling this aspect of morale resulted in public defiance of the policy. Sections of the dance industry led the way. Large hotels in London's West End were amongst the first to bring back dancing. On September 14, the Berkeley Hotel issued a statement declaring: "We are starting dancing again in response to mass requests. After all, what is the use of sitting looking at each other...Dancing will make people forget their worries." 17 By the beginning of October, some local authorities outside London were permitting extensions for late night dances at hotels, using similar arguments about morale. Brighton Mayor, J. Talbot Nanson justifying one such license exclaimed: "We feel it is our duty in the national interest to keep up the spirits of the people and encourage legitimate forms of entertainment." 18 Such sentiments represented a sharp reversal of attitudes towards dancing at local government level, as many magistrates had waged a battle against dance halls via licensing throughout the interwar period. ${ }^{19}$

After the bombing began in earnest from the autumn of 1940, however, government had to reconsider its policy once again. Now that mass bombardment of Britain's urban centres was a reality, should dance halls be closed to avoid mass casualties? Luckily the new coalition under Churchill contained some who were more in touch 
with the lives of the majority of the population. Thus, in March 1941, following the bombing of several dance halls, the Ministry of Home Security finally considered the question of whether dancing in public halls should be allowed during air raids. Home Secretary Herbert Morrison decided that there would not be any official prohibition of night sessions at dance halls. Weighing up the risk of casualties against the impact on morale, government advice was now that the public themselves had to decide what action they took in the event of air raids. Thus, dancers were to be informed of an alert and then left to make their own decision whether or not to go to the nearest shelter. Clearly Morrison, himself a keen dancer, had a better sense of the importance of dance halls to morale. In a memorandum to the War Cabinet in February 1942 he argued that "the harder the work the greater the need for some degree of reasonable recreation. An excessive interference with customary recreation might defeat its own ends by lowering morale and this, in turn, might affect production." ${ }^{20}$ Here is evidence then, of a grudging and gradual acceptance of the importance of dancing in maintaining morale.

How did the Blitz affect dancing and what role did dancing play in maintaining morale at this critical hour in Britain's history? Initially, the Blitz scared many patrons away from dance halls. In October 1940 Dancing Times noted an "air of gloom" in the capital, stating "Dancing in London has been seriously hit by these chronic raids." ${ }^{21}$ In Bristol too it was reported that some dance promoters were afraid to take the risk of organising dances because air raids were scaring dancers away. ${ }^{22}$ However, as populations became more familiar with blitz conditions they gradually began to return to city centres. By October 1940 Mass Observation noted that "There is a small section of people (mostly young) who have become completely accustomed to the raids; go out and enjoy themselves in the evenings; wander about the streets in 
the barrage, in spirit not of bravado, but of indifference." It went on "now young people are going to the West End for dancing. etc. The Astoria, for instance, is a popular place for young people from the East End to go, because it 'takes you out of yourself', and then we stay there the night. 'It's safe there, and we're all together, so don't hear the noise." ${ }^{23}$ What started as a drift back to town and city centres became the start of a golden era in the popularity of dancing in Britain, and not just among the young.

Significantly, this taste for dancing became an important part of the nation's self-constructed 'myth of the Blitz.' Once dancers returned, a resilient spirit of 'carrying on' was reported in the press, as dance halls became symbols of normality and resistance. Dance halls worked hard to bolster a self-image of defiance. At the Grafton Rooms in Liverpool, the management advertised itself as "Liverpool's Bombproof Ballroom" and it had a policy of carrying on dancing during alerts and barrages, with Mrs Wilf Hamer conducting the orchestra wearing her tin hat during air raids. ${ }^{24}$ In November 1941 dancers in the West End carried on dancing despite a heavy calibre bomb dropping next to them. The event was broadcast live on the BBC, since Jack White and his orchestra were performing. The press reported it with a keen eye on its propaganda value:

Two hundred couples were dancing on the crowded floor. Suddenly a heavy thud shuddered through the sprung maple floor. Crashing of glass followed. Clouds of choking brick dust covered the dancers. On the music dais the pianist shot off his stool. The trombone player's silver instrument flew from his hand across the room. 'Carry on, boys, keep playing,' said the band leader - and prevented what might have been panic...Brushing 
plaster and brick dust from their clothes, the dancers began the 'Lambeth Walk. ${ }^{25}$

Dancing and dancers became part of the armoury in Britain's morale war - they provided plentiful evidence of a spirit of stoicism and bravery. Beyond these propagandist images of dancing and dance halls, dancing performed morale raising roles in several other different ways. Most fundamentally, it offered distraction at a time of intense stress. Thus, dancing in air-raid shelters was one way in which the minds of those sheltering could be pre-occupied. In its Sixth Weekly Morale Report of September 1940, for example, Mass Observation noted that even though morale in shelters could be low, it "can be kept up by conscious efforts like singing, dancing etc." Indeed the report commented that some were even forsaking their own private shelters in preference for communal shelters because of their sense of comradeship and 'jollity,' often promoted by dancing. "Liveliness is the thing most sought during a raid. Minds must be kept occupied..." It went on: “I'm going into the public one tonight' one young woman said on Tuesday, 'they have singing and dancing there well, why not? Its no good sitting moping." ${ }^{26}$ Dancing during air raids was good for morale, then, because it offered an attractive alternative, especially for the young.

Dancing also offered a distraction for communities which had been heavily bombed. It took their minds away from the destruction caused and created a sense of 'normality.' In illustration of this, Mass-Observation, working together with Home Intelligence, carried out a series of investigations into morale in blitzed areas between the end of 1940 and end of 1941. Coventry, Bristol, Southampton, Leicester, London, Liverpool and Manchester were all subject to surveys. Importantly, these investigations pointed to the signficance of entertainment, especially dance halls and 
dancing, to the maintenance of morale. In those blitzed cities with an active nightlife, the spirits of the local population were reported to be more buoyant than in those areas where bombing had disrupted nocturnal leisure activities. For example, Liverpool was noted to have very high morale when compared to Manchester. Although there were a variety of explanations for Liverpool's more robust morale the nature of the bomb damage in the city, the presence of large numbers of sailors, and an underlying resilience and toughness of character born out of pre-war hardship dance halls were given special mention, and full dance halls at night were regarded as one indication of 'good morale'. ${ }^{27}$ As Mass Observation noted, "In Liverpool you can still find five hundred people in a dance hall with an enemy plane overhead." 28 Moreover, such facilities were regarded as playing a part in maintaining a lively night time atmosphere in the city in general:

The centre of Liverpool after dark is a mixture between a bump supper night at Cambridge... and a Bank Holiday at Blackpool. Nowhere have we seen more drunkenness, more singing and shouting and catcalling, more picking up, or more people being sick. ${ }^{29}$

In comparison, "going from Liverpool to Manchester was like going from an atmosphere of reasonable cheerfulness into an atmosphere of barely restrained depression." Mass Observation concluded that one of the main reasons for this was that in Manchester night entertainments closed down during raids. It reported only one dance hall open in the city centre, and that only contained 60 people. ${ }^{30}$

A similar contrast was found in Portsmouth and Plymouth. Portsmouth, where morale was regarded as poor, also saw a panic-stricken closing down of its nightlife during raids, with even pubs closing their doors, and no cinemas opening late. Like Manchester, there was one dance hall open in the city centre, the Empress, where 120 
men, mostly sailors, milled around only 40 girls. ${ }^{31}$ In Plymouth, there was "cheerfulness everywhere and a real "carrying on." ${ }^{32}$ As in Liverpool, the city's nightlife was maintained during the air raids, and was described by Mass-Observation as "terrific." ${ }^{33}$ It was noted that dance halls were crowded, along with pubs, cinemas, amusement arcades and theatres.

Mass-Observation and Home Intelligence thus concluded that it was vital to keep dance halls open in the aftermath of bombing, and recommended that they be made repair priorities. Linked to this, Mass-Observation suggested that to make morale more 'active' people had to be given 'focal points, on to which they can direct their feelings, fears and hopes." It suggested, therefore, that "Everything possible should be done to facilitate the use of leisure and pleasure outlets." ${ }^{34}$ It went on:

repairs for places of entertainment should be a first priority in the post blitzed situation. During a week a majority of the population can get relief and encouragement from these places. We are completely unable to understand why after a blitz the local authorities should frequently consider it desirable to compulsorily close or restrict entertainments. For instance, in Plymouth...no cinema or dance hall...was permitted to function. Even dance places in small rooms were prohibited...There are no doubt good reasons for this, but they are not good morale reasons. And entertainment is primarily a morale matter. ${ }^{35}$

Indeed, Mass Observation went on to recommend that the government pay far greater attention to post-blitz morale, and to take positive, co-ordinated action to help bombed areas recover. ${ }^{36}$ It suggested that: 
energetic measures should be taken to encourage post-blitz entertainment and to improvise emergency entertainments at once. Some towns remain places of dead leisure literally for weeks after their raids; there is nothing to do but drift around and look at the damage... ${ }^{37}$

Self-consciously then, the dance hall industry worked to promote itself as an important part of the mythologizing of the Blitz, securing a place for dancing as part of Britain's wider image of defiance and resistance in the face of danger.

\section{DANCING AND WARTIME TRANSITIONS}

Dancing was also an important means by which wartime transitions could be eased amongst some of the most important sections of home front society. The dislocation caused by evacuation, conscription and the relocation of elements of the population was partly ameliorated by the use of a familiar institution and pastime. This proved particularly significant for women, who were both the most prolific dancers and amongst the most vital of war workers.

As Robert Mackay has noted, one of the key focuses of government propaganda after 1940 was women. ${ }^{38}$ The growing realisation of their importance to the war effort resulted in a host of initiatives designed to galvanise them into action. As a result, the historiography of the Home Front includes numerous studies of campaigns aimed at women. ${ }^{39}$ What is less well known is that dancing and dance halls were also utilised in order to make war work more attractive to women. Their sociability was used in order to help women familiarise themselves with their new environments. Mass Observation, for instance, noted that in canteens and factories informal dancing to radio during recreation hours was a very popular pastime. ${ }^{40}$ Elsewhere, arrangements for dancing were more formal. In 1941, several war 
factories in Coventry provided dance bands and facilities for dancing, some holding two midday concerts per week, and one even running dances from midnight to $1 \mathrm{am}$ in response to demands from younger workers. ${ }^{41}$ In Edinburgh similar demands led the management of one large munitions factory to open a dance club for its' employees:

We have decided to open the hall at 4 o'clock in the afternoon so that those on night-shift may have a few hours dancing before going to work...We are certain that by bringing the workers together like this they will get to know one another better and will look forward to meeting at their benches in the morning. ${ }^{42}$

At a RAF factory in northern England, the popularity of dancing as a recreation for workers was reflected in the provision of a "magnificent ballroom" and a number of dance clubs where tuition was given. ${ }^{43}$ As with the BBC's 'Music While You Work', it was argued that the provision of dancing facilities during breaks increased productivity. Thus, in August 1941 Dance News reported that:

More and more war factories are to have schemes for holding dances for their employees. This is because reports show that wherever dances have been arranged, they are popular, benefit the health of the employees, keeps them "smiling" - and improve work output. ${ }^{44}$

However, this was not just dance industry self-promotion. Taking its lead from these private initiatives, the Ministry of Labor encouraged dancing via the establishment of social centres in war factories to help newly-mobilised women to acclimatise themselves to their new surroundings. In September 1941, for example, the Ministry arranged for free dancing and cabaret entertainments for registered women who had been sent to a large Royal Ordnance factory on the outskirts of London. In 1942, the government even sponsored a 'dancing master', a retired ballroom champion, in 
engineering factories in the north west of England to give dance lessons and physical training instruction to the workforce. ${ }^{45}$

Members of the Women's Land Army also looked to dancing as a means of relaxing and socialising off duty. Again, private initiative led the way. Letters written by the women, many of them from the larger cities, and now stationed in isolated parts of the country, pointed to the importance of the 'village hop': "as being one of the things that seem to make life worth living again after an eight hour day down on the farm." 46

Evacuated mothers were also encouraged to dance in an attempt to ease their wartime lives. For example, dancing was used in a campaign to try to halt evacuated mothers returning to Scottish cities. To this end, in November 1941 the Scottish Department of Health made plans for scores of clubs to be established for evacuees. It wished to provide clubrooms, film and recreation centres in every reception area. As one reporter remarked: "Folk in the country haven't any cinemas, theatres and first class dancehalls. This new Government innovation can be interpreted as a move to ensure that these mothers, many of them of the 'dance mad' variety, will settle down quickly and stay in their new and at first somewhat strange surroundings. $" 47$

It soon became apparent to the service ministries that dancing could also be used to ease the boredom of military life. As the quotation at beginning of this article illustrates so vividly, for men and women in uniform dancing became a key feature of wartime British life. Yet military attitudes to the value of male dancing were often confused. Was it good for the image of the armed forces for servicemen to be seen dancing in uniform? Was this activity 'masculine' enough for those who were about 
to go into combat? In 1940 W. Heath of the London Welfare Branch of the War Office made the case for dancing for servicemen:

One of the finest exercises for the troops is to dance. They are brought into association under good conditions. They have the opportunity of listening to bright, breezy music. In good class dance halls they have cheery illuminations with picturesque decorations and everything combined to give an atmosphere of happiness and jollity. ...the whole thing is a system of physical training taken under pleasant conditions. ${ }^{48}$

That winter, Anthony Eden, the Secretary of State for War, agreed that dancing was one of the entertainments that should be available to soldiers, ${ }^{49}$ and by 1941 the War Office was encouraging dancing as a way of overcoming boredom and encouraging conventional morality. "If possible”, it stated, "'sleeping out' passes should be given to the married men whose wives go along to a dance with them."50

Many military bases created facilities for dancing as part of their entertainment facilities. At Donnington Army Depot in Cheshire, for example, a large Nissen hut was used as a theatre capable of accommodating 1000, and the men voluntarily laid a dance floor so that they could dance. Dances were held once a week, run by a dance committee, and there were additional dances run by the YMCA and NAAFI which also had facilities on the base. ${ }^{51}$ Similar arrangements were made at camps throughout the country. As Lance Corporal A. H. Franks told Dancing Times in January 1942:

In most army camps ballroom dancing is indisputably the chief form of amusement all the year round. Gymnasia are large and plentiful; the floors, although not sprung are usually of well laid blocks... The bands are as a rule first rate...In any garrison area there are many thousands of men, and every dance (one is held almost every night) collects a full house. ${ }^{52}$ 
Dances were also arranged offsite, aided by transport provided by the military. The Entertainments and Welfare Officer of a unit would often organise such functions in nearby dance venues specifically for their men. When dances were not laid on especially for them, servicemen would invariably go to local public dances instead. One soldier remarked: "When...I've been thoroughly 'browned off' ...I have decided that there's only one thing to do - trot along to a dance. And more often than not...I've taken myself off to the nearest Palais or barn...and returned feeling happier...for my visit." 53

Meanwhile dancing was increasingly used to help injured servicemen to recover. In September 1944 Danceland reported from an RAF Rehabilitation Center on the north-west coast where dancing had been prescribed by doctors as part of the cure for injuries sustained by members of RAF bomber crews. Initially introduced as a form of social welfare, it was soon taken more seriously by surgeons, who found it to be a useful aid to those with amputations and other injuries: "It was found that under the influence of bright dance tunes, plus patient partners, many men who were hesitant about putting their weight on an injured limb, even during the ordinary remedial exercises, would do so readily when dancing."

\section{III: DANCING, 'COMMUNITY CAMPAIGNS' AND PROPAGANDA}

In addition to acting as 'jam' for the general population, one of the most important features of dancing for the war effort lay in its ability to engage the civilian population in 'community action' in support of various aspects of the fight against Germany and its allies. The dance hall was a particularly effective tool for mobilising the civilian population because it was an institution that had embedded itself strongly in civic society by 1939. Moreover, by throwing itself wholeheartedly into war- 
related campaigns, the dance hall industry further extended its role in creating images of sacrifice and provided examples of a spirit of voluntarism and philanthropy. All were useful in helping to overcome prejudices against social dancing amongst critics. Existing scholarship on wartime popular culture has already noted how both radio and cinema were used to try and explicitly link the Home Front and the Fighting Front, and also how the concept of a 'People's War' was central to their propaganda messages. Scannell and Cardiff, for example, highlight how through 'industrial features' programmes, the wartime $\mathrm{BBC}$ brought members of the armed forces together with the industrial working class in broadcasts highlighting their shared fight and indebtedness to one another. ${ }^{55}$ Furthermore, factory based audience participation shows like 'Works Wonders', and programmes focusing on particular civil defence units such as 'Ack, Ack, Beer, Beer,' were a vital part of the exaltation of the working class in an attempt to show them as 'everyday heroes' vital to the nation's war effort. Many of these programmes backfired however, as the public saw the BBC's efforts as too obviously propagandist and hectoring. ${ }^{56}$ Dance halls, however, proved to be much more effective conduits for government messages.

The need for the active engagement of the public with wider war aims was recognised relatively early on by the government, largely due to the groundswell of complaints picked up by Home Intelligence. As Ian McLaine has pointed out, engagement in the war effort was seen as both an indication of, and cause of, 'high morale,' but morale was "meaningless, or at least ineffective, unless it promotes action." 57 This notion of personal involvement in the war effort was recognised as being of key importance. As a result, the Ministry of Information developed a series of 'community action' campaigns designed to bolster morale and thus the war effort. The War Savings 
Campaign is a good example as it encouraged direct involvement of both individuals and communities in the war effort. Savings groups were organized locally throughout the country centred around specific fund raising efforts. These included the 'Spitfire Fund' (1940), 'War Weapons Week' (1941), 'Warship Weeks' (1941 / 1942), 'Wings For Victory Week' (1943) and 'Salute the Soldier Week' (1944). The pattern of these campaign weeks involved a community being set a fundraising target. During the week, the organising committee arranged events in support of the campaign, which might include speeches by decorated war heroes and visits by government ministers or royalty. Dances were often at the centre of such Savings Campaigns. For example, in 1941 Glasgow raised $£ 12$ million as part of a 'Warships Week.' Dances were held throughout the city to raise funds. ${ }^{58}$ In 1944 , dancers in Campbeltown raised $£ 55$ for their 'Salute the Solider' dance week. ${ }^{59}$ Local communities also took the initiative by establishing their own war saving priorities and campaigns. In 1943, Tredegar District Council put on a week long dancing programme at its open air baths, which attracted more than 1000 people each night, to raise funds for the local Troops' Comforts Fund and the Old Age Pensioners' Association. ${ }^{60}$

Perhaps more significantly, the dance hall industry actively threw itself into fundraising for the war effort, and the Mecca chain of dance halls was particularly influential in encouraging those in the industry to make use of its venues for such purposes. For instance, in 1942 there was an urgent need for more tanks and Mecca's Dance News made an appeal to dance halls: "Dance News appeals most strongly to every dancehall manager to assist in raising funds for tanks. Approach your local town hall immediately and obtain permission to take collections. You can do so much - the dancing public were always generous." ${ }^{61}$ By 1942, under the leadership of 
Mecca's Carl Heimann, the dance hall industry was making a co-ordinated attempt to raise funds for the war effort. A 'Dancers Victory Fund' was established in February 1942 and by 1944 it had raised over $£ 5$ million. ${ }^{62}$

More than simply raising funds, however, dances were linking the home front with the fighting fronts by explicitly connecting military events with events in the dancehall. For example, in November 1941, Dance News reported that: "Hundreds of dancers wended their way homewards from Edinburgh's Palais De Danse this week knowing they had helped to avenge the loss of the Prince of Wales and Repulse battleships in the Pacific on Wednesday last. It was Warship Week with a 'capital' W all right at the Edinburgh Palais. Nautical tunes gave a real naval flavour to a dancehall in which the notes of patriotism and jollity were well blended." A model of the Ark Royal on wheels was moved around the dancefloor to collect money and the hall even came up with its own motto song:

This little ship was built at the Palais,

Give your pennies and tanners, don't dilly dally, Help Our Navy to knock Hell out of the Nazis, Thanks in anticipation my dear Lads and Lassies. ${ }^{63}$

Linked to this, dance hall managements used servicemen as 'features' in their halls. Halls became the venue for civilians to meet those actively involved in the fighting, in a way that eulogised the efforts of the armed forces, further helping in the construction of heroic images for the nation to admire. In August 1941, for example, three "famous fighter pilots" were present at the Carnival Dance held at the Regent Dance Hall, Brighton, in aid of the Brighton and Hove District Air Training Corp. ${ }^{64}$ 
Some dance halls even provided special gifts for servicemen. At the Plaza Ballroom, Derby, in January 1942, the management secured the attendance of nine local sailors from the 'Ark Royal' who were each given 100 cigarettes, a wrist watch and shaving outfit. All other sailors were admitted free and given complimentary refreshments throughout the evening. ${ }^{65}$

It was not only combatants who were celebrated in Britain's wartime dance halls. As part of the 'People's War' concept of highlighting the importance of home front contributions to the war effort, dance halls were used as venues to mark the contribution of civil defence workers. At the height of the Blitz in London there were a large number of these events. For example, in July 1941, nearly 2000 dancers and spectators were present at the Locarno Dancehall, Streatham for a Civil Defence Services' Ball. All sections of the ARP, Home Guard and Firewatchers were represented and comedian Leslie Henson gave out prizes to winners of various wardens' and shelter marshalls' competitions. ${ }^{66}$ The following month Admiral Sir Edward Evans, in charge of Civil Defence for London, attended the first of a series of balls organised by the London Ambulance Benevolent Fund, which provided assistance for its members injured in the blitz, held at the Royal Opera House Covent Garden. ${ }^{67}$

In addition to these laudatory roles, dance halls actively sought to link themselves with wider government propaganda campaigns. Thus, for instance, in July 1941 dance halls throughout Britain took an active role in connecting themselves with the ' $\mathrm{V}$ ' campaign. This campaign encouraged those in occupied Europe to daub the ' $\mathrm{V}$ ' sign everywhere as a symbol of belief in Allied victory and as an act of defiance. It was 
popularised via BBC broadcasts to the continent, using the morse code for ' $\mathrm{V}$ ' (three dots and a dash), which coincided with the first bars of Beethoven's Fifth Symphony, used as a call sign. In Britain's dance halls, special features and stunts were arranged to show solidarity with this campaign that reinforced the public image of dance halls as patriotic supporters of the war effort. In one West End dance hall in London two large banners were hung outside proclaiming that all those whose name began with ' $\mathrm{V}$ ' would be admitted free. In a Leeds dance hall, a five foot illuminated banner in the shape of a huge ' $\mathrm{V}$ ' intermittently flashed out the signal in morse. A local vicar congratulated the venue on using the ' $\mathrm{V}$ ' as 'a sign of the united front against Hitler...to link ourselves symbolically with those who are suffering abroad and awaiting our triumph. ${ }^{68}$ Justifying this campaign in suitably patriotic terms, Dance News wrote that 'Here in Britain we are proud to boast about victory openly. Men and women in the Forces, the workers in the factories, ARP workers, after a hard day in their own particular sphere, like to relax in places of entertainment and publicly air their views that Victory is bound to come. Some columnists in National newspapers say that this ' $\mathrm{V}$ ' campaign at home is pointless and rather silly. Our advice to such columnists is that they should undergo a study of the psychology of the public. ${ }^{69}$

Dance halls became important vehicles for other war-related information campaigns too. During the Blitz, Mecca advised dance hall managers to cooperate with local ARP authorities and run special 'gas mask dances' and "thus encourage the cultivation of the 'gas mask' habit by the public."70 This message was brought home to dancers in an uncompromising fashion in one 'provincial' dance hall in July 1941 when the management told dancers to make sure they had their gas masks as the following night they would be releasing a 'tear gas' in the hall. Which they did! ${ }^{71} \mathrm{~A}$ less dramatic way of encouraging gas mask use was employed by the Streatham 
Locarno, where on Monday Nights, 'Gas Mask Night,' a 3d reduction was given to all civilians bringing Gas Masks.

\section{IV: DANCING AND BRITAIN'S ALLIES}

Dancing also served a diplomatic function during the war, used at both official and unofficial levels as part of efforts to woo Britain's friends and allies. It also served as a means of introducing the culture of the Allied nations to the British population, and for smoothing relations between them. As existing historiography on dancing during the war has noted, the reality could often be more complex and dance halls were the scene of considerable racial and xenophobic tension between Britain and her allies. ${ }^{72}$ This is not the whole story, however. During the war itself, they were put to use as another part of the self-constructed 'myth of the Blitz.' Such conflicts were 'screened out' and images of dancing and dance halls as opportunities for co-operation and understanding were promoted. As an example, the thousands of Poles who had escaped their country at the start of the war were a highly visible presence in wartime Britain. There came to be some 195,000 Polish members of the armed services under British command during the war, with Polish Army, Navy and Air Forces located throughout the country. Via dancing, attempts were made to integrate them better into British society. In November 1941 a 'Polish Night' was held at the Royal Opera House dance hall which featured another display of Polish dancing in aid of the Polish Army Comforts Fund. That same month in Liverpool the local Anglo-Polish Society held a display of Polish dancing at British Council House, a social centre for foreign members of the Allied Forces and merchant fleets. Polish pilots, observers and air gunners danced, and local girls were asked to join in. The dancing provided real opportunities for interaction. As one report stated, "It was remarkable how quickly 
and surely the English girls did pick up the steps, some of them rather intricate. By the end one would have imagined that the more expert girls had been doing Polish dances from their toddling days." 73

The USA was another target of dance hall diplomacy. Dances were used as a way of fostering Anglo-American solidarity whilst it was still in its isolationist phase up to December 1941. At such dances, the links between the two countries were emphasised and they were used as an arena for expressing shared values. For example, on Thanksgiving Day in November 1941 a dance was arranged in London by 'The Kinsmen,' an organisation formed by parents whose children had been evacuated to the USA, to entertain Americans in Britain as a gesture of thanks. About 200 Americans were present, including nurses, technicians, members of the various services, and staff of the American Embassy. Indeed, it received official sanction at the highest level - Eleanor Roosevelt sent a telegram highlighting the common traits between Britain and America. "Times to come may still be hard", she wrote, "but the spirit of free men has proved itself unconquerable and each day brings near its victory." On the British side, guests included Lady Tweedsmuir, Sir Harry Britain, Mrs Beatrice Warde and Mrs A.V. Alexander, wife of the First Lord of the Admiralty. Entertainment was provided by Leslie Henson, Stanley Holloway, Carroll Gibbons and an RAF Band. To ensure the full propaganda value of the dance, it was recorded and broadcast to the USA by the BBC. ${ }^{74}$

Once the bombing started in earnest, dances were another way of trying to persuade the USA to join the war. Capitalising on the sympathetic war reports of American broadcasters such as Ed Murrow, dances were a key diplomatic tool. A Five Hours 
Gala dance, in aid of the All London Fire Services Benevolent Fund, was held at the height of the Blitz in 1941 in south London. Along with 2000 firemen and their wives, representatives of the American Embassy were present. The American reporter, Quentin Reynolds, who the Ministry of Information had used to introduce their propaganda film, London Can Take It in 1940, sent a message of support and the noted American journalist Dorothy Thompson, the first foreign journalist to be expelled from Nazi Germany and a strong anti-isolationist, told the guests that "I want to congratulate you all on your courage, and even more than that, on your good humours. Even in times like these you can laugh, I should say laugh more than any other people in any country - and that's why you're going to win." 75

Once in the war, and based in Britain, dances were one of the most significant points of encounter between the American servicemen and their British hosts. Three million US troops arrived in Britain from 1942 onwards and dancing was one of the favourite leisure time activities of these American visitors. Early in 1942 many dancehalls in Britain planned American balls to celebrate President Roosevelt's $60^{\text {th }}$ birthday $^{76}$ and Mecca's Carl Heimann decided to offer free admission to his venues for American servicemen during the first few months of their service in Britain, together with free dancing lessons. As Heimann put it: "We will give American troops a real royal welcome in any of our Mecca dancehalls...please extend invitation to visit halls as our guests." 77 In the meantime, Dance News reported on the first experiences of the US troops in Northern Ireland's dance halls: “On their first night many were given leave and they found their way into dance halls and cinemas. In the dancehalls they quickly made themselves at home among the friendly crowds, and were soon dancing with zest. Dances and parties were arranged impromptu fashion by local inhabitants 
who invited the Americans along."78 It went on "This week's arrivals showed that they are just plain ordinary folk like ourselves, helping in a big job and aiming to get it over as quickly as possible. If we meet them on that common ground we shall get along all right."79

In order to smooth their arrival, such publications as Dance News started a regular weekly feature for Americans in Britain. It also called on its British readers to welcome their allies:

Don't treat them as strangers. Make them really welcome and give the lie to that wrong impression that we are an insular people.

Remember that their ways of life are in many respects quite different than ours. Don't make a joke of what might appear to be their 'funny' ways. Some of the ways we do things might appear just as funny to them. Discuss difficulties with them reasonably and if you cant quite see their point of view, don't make a song about it. ${ }^{80}$

Moreover, British dance halls were responsive to American demands and were an important way of welcoming American servicemen. In Liverpool in October 1942, for example, the Grafton Rooms ran an 'American Dancing' night that month, with demonstrations of American styles, and a Swing dance competition was also held. One of the biggest Liverpool stores gave an exhibition of American dancing. Elsewhere, the arrival of the Americans at the Paramount, Tottenham Court Road, London, led to a revival of interest in the Jitterbug. ${ }^{81}$ Covent Garden Opera House and the Hammersmith Palais also became centres for Jitterbug dancing, with American soldiers using the halls every afternoon and evening to practice the dance with English girls. ${ }^{82}$ In addition, interaction was generated in the Anglo-American 
friendship clubs that sprang up in towns and cities across Britain. Again, dancing was central to such encounters. For example, in 1944 a British 'Welcome Club' was opened in Shenstone, Staffordshire for American serviceman, and the opening night dance included a jitterbug contest. $^{83}$ In Cheltenham, 'Anglo-American Entertainments' were put on at the Holy Apostle's Hall, Charlton Kings, with music supplied by the American Red Cross Dance Orchestra and the 'Swing Wings.' Jitterbug demonstrations were given by Corporal Frank Wroblewski. ${ }^{84}$

\section{CONCLUSION}

Dance halls helped to make a reality of propaganda slogans by actively involving British citizens in the war effort, and in a context in which they enjoyed socialising. Moreover, although they tied in with official government propaganda aims, the fact that such messages were spread by such key institutions of civic society - popular entertainment venues - made them all the more effective.

That dance halls were used in this way reveals both the weaknesses and strengths of the British government's war effort. Their utilisation was neither straightforward nor easy. Much of the impetus for the use of dance halls for this purpose came from private initiatives - from sections of civil society or from the dance hall industry itself - with the state only following this lead, and not always open to offering its full support. There is little evidence to suggest that the government directly pressurised dance halls to act in the way that they did. Indeed, the dance hall industry offers of help were often spurned or met with a lack of action. For example, in 1941, Mecca offered to co-ordinate attempts to provide dancing facilities for munitions workers by the Ministry of Labor and Ministry of Supply, but the offer was not taken up. ${ }^{85}$ Furthermore, it was an indication that the government did not 
consider dancing particularly important to the war effort that it refused accept requests from Mecca to classify dance hall staff as in a 'reserved occupation.'

So why did the dance halls do what they did? There were obvious business reasons for taking the pro-active stance that they did. War work and fund raising not only raised the profile of the dance hall industry, but also protected it from accusations that dancing was an unnecessary and flippant distraction during a time of national peril. Furthermore, such events made sure that local businesses maintained their public profile and cemented their importance in the local community and its cultural life. However, it is also clear that many dance hall managements were motivated by a genuine sense of patriotism and duty. Carl Heimann of Mecca was a good example of this. A Danish-born immigrant, his wartime writings, issued to his staff via a 'Weekly Bulletin', display a real love of his adopted country and a keenness to serve it. Outlining 'Our Policy' in 1942, his first priority for Mecca and its staff was "To show 100 per cent loyalty to our country in all our actions." 86 In 1944 he issued a similar statement of his company's intent: “To do nothing that is against the Nation but to do everything that the Government requires of a law-abiding citizen. These things first: the weal of the Nation, the avoidance of all who would hinder the War effort or take our minds off our jobs." ${ }^{87}$ Heimann was acutely aware of the importance of dancing and dance halls to maintaining morale and of the power of a 'positive outlook.' In a staff meeting in June 1941 he urged his colleagues to:

Talk Success... You are an important part of the public - don't, whatever you do, indulge in defeatist talk. This is very important - especially for the next month or two. This is a time when the British Public must stand together, and I ask you to be both loyal to us and loyal to your country. We shall only survive if we are fit to survive as a nation. Don't spread 
rumours...it is important that you cultivate the mental attitude of survival.

Don't be alarmist - the Germans are relying on pessimism. ${ }^{88}$

However, there were many critics of dancing, heirs of a long tradition of sceptics who considered the pastime 'immoral,' 'flippant', or 'unhealthy.' 89 Although it has not been possible here to outline the views of wartime critics, there were many who condemned dancing as a distraction, not an aid to the war effort. Doctors, politicians and clergymen lined up to blame dancing for absenteeism amongst young war workers, and countless more considered it shameful to be 'living it up' whilst the war was raging. Indeed, women in particular came in for considerable criticism for this reason. Accusations of immorality amongst women who danced were rife, and both civilians and those in the forces were condemned for becoming 'good time girls.' Furthermore, the use of dancing to cement relations with wartime allies was one riddled with danger. Dancing could cause considerable headaches for the authorities when fights broke out in dance halls, for example, between British and American troops, and black and white American servicemen. Foreigners dancing with British women were the cause of much jealousy.

Despite all of these difficulties, however, the government, under the wise guidance of Herbert Morrison, refused to countenance needless restrictions on dancing. Recognising their importance to the war effort, albeit hesitantly, the authorities facilitated this popular pastime. Moreover, dancing and dance halls proved to be vital in helping the British population endure the hardships and turmoil of war - providing an important means of escape, relaxation and sociability, as well as serving a crucial role in creating a 'mythology' of the Blitz - with its images of heroism, stoicism, 
resilience and defiance - necessary for the psychological strength of the British population.

${ }^{1}$ Dancing Times (DT), Dec 1942, 147

${ }^{2}$ Mass-Observation Archive (M-O A) FR634, "Broadcast for North American Service, 20.4.41," 7

${ }^{3}$ Dance News (DN), Nov 14, 1942, 5

${ }^{4}$ See, for example, J. Gardiner, Over Here: The GIs in Wartime Britain (London, 1992) and D. Reynolds, Rich Relations: The American Occupation of Britain 19421945 (London, 1995)

${ }^{5}$ R. Mackay, Half the Battle: Civilian Morale in Britain During the Second World War (Manchester, 2003)

${ }^{6}$ See, for example, on radio: D. Cardiff and P. Scannell, “Good Luck War Workers: Class, Politics and Entertainment in Wartime Broadcasting” in T. Bennet et al (eds), Popular Culture and Social Relations (Milton Keynes, 1986), 93-115; S. Nicholas, “The People's Radio: The BBC and its Audience, 1939-1945” in N. Hayes and J. Hill (eds), Millions Like Us? British Culture in the Second World War (Liverpool, 1999), 62-92. For cinema, see P. M. Taylor (ed), Britain and the Cinema during the Second World War (London, 1988); J. Chapman, "British Cinema and the 'People's War"” in Hayes and Hill, Millions Like Us?; R. Murphy, British Cinema and the Second World War (London, 2000) and P. Stead, "The Wartime Drama of the Common People" in Film and the Working Class (London, 1999). On other wartime leisure activities, see Hayes and Hill, Millions Like Us? and C. Baade, Victory Through Harmony: The BBC and Popular Music in World War II (Oxford, 2011) 
${ }^{7}$ I. McLaine, Ministry of Morale: Home Front Morale and the Ministry of Information in World War II (London 1979). See also Mackay, Half the Battle

${ }^{8}$ See for example, A. Calder, The Myth of the Blitz (London, 1991); H. Smith, Britain in the Second World War: A Social History (Manchester, 1996); P. Clarke, Hope and Glory: Britain 1900-1990 (London, 1996); Mackay, Half the Battle

${ }^{9}$ Jeffrey Richards and Nicholas Pronay, for example, have shown how the cinema was regarded as a social, moral and political threat in the interwar period and elicited a number of responses designed to control and sanitise it. See J. Richards, The Age of the Dream Palace: Cinema and Society in Britain 1930-39 (London, 1984); N.

Pronay and D. W. Spring (eds), Propaganda, Politics and Film 1918-1945 (1982)

${ }^{10}$ J. Chapman, The British at War: Cinema, State and Propaganda 1939-45 (London, 1998); R. Murphy, British Cinema and the Second World War (London, 2000)

${ }^{11}$ See Cardiff and Scannell, "Good Luck War Workers" and Nicholas, "The People's Radio"

${ }^{12}$ See J. Nott, Going to the Palais: A Social and Cultural History of Dancing and Dance Halls in Britain 1918-60 (Oxford, 2015) 217-19; and J. Nott, "Contesting Popular Dancing and Dance Music During the 1920s," in Cultural and Social History 10.3 (September, 2013), 439-456

${ }^{13}$ McLaine, Ministry of Morale

${ }^{14}$ M-O A FR11A “Jazz and Dancing, Nov 1939,” 26

${ }^{15}$ M-O A TC Propaganda and Morale 1939-44, 43-2-A: “Typed extracts re propaganda and the MoI: 7.9 TH” (1939)

${ }^{16}$ The Spectator, Sept 8, 1939, 2

${ }^{17}$ Daily Mirror (DM), Sept 14, 1939, 5

${ }^{18}$ Daily Express, Oct 3, 1939, 3 
${ }^{19}$ See Nott, Going to the Palais, ch.10

${ }^{20}$ PRO Kew, CAB/66/22/31, War Cabinet: H. Morrison, Memorandum "Public

Entertainments," Feb 27, 1942, 2

${ }^{21} D T$, Oct 1940, 27

${ }^{22}$ DT, Dec 1940, 169

${ }^{23}$ M-O A FR449 "Second Weekly Report For Home Intelligence”, Oct 1940, 31

${ }^{24} D T$, Dec 1940, 165

${ }^{25}$ Modern Dance and Dancer (MDD), Nov 1940, 17

${ }^{26}$ M-O A FR381 “Sixth Weekly Morale Report," Sept 1940, 8A

${ }^{27}$ M-O A FR538 “Liverpool and Manchester,” Dec 1940, 3

28 ibid, 4

${ }^{29}$ ibid, 7-8

${ }^{30}$ ibid, 13

${ }^{31}$ M-O A FR559 "Portsmouth and Plymouth," Dec 1940, 4

32 ibid, 17

${ }^{33}$ ibid, 19

${ }^{34}$ M-O A FR633 "Need for an Offensive Morale, April 1941”, 4

35 ibid, 6

${ }^{36}$ M-O A FR722 “Social Welfare in Blitz Towns, June 1941”, 1

${ }^{37}$ ibid, 4

${ }^{38}$ Mackay, Half the Battle, 174

${ }^{39}$ For example, there has been considerable work examining the government's use of film and radio to overcome women's reluctance to be mobilised into industry for the war effort. Film such as "Million's Like Us" (1943) were commissioned by the Ministry of Labor with the explicit aim of confronting female hostility to working in 
factories. The BBC also played its part, with the introduction of 'Music Whilst You

Work' in factories partially a result of the need to make industry more attractive to women. See A. Lant, Blackout: Reinventing Women for Wartime British Cinema (Princeton NJ, 1991) and S. Harper, Women in British Cinema: Mad, Bad and Dangerous to Know (London, 2000), 30-50

${ }^{40}$ M-O A FR 1496 “Tube Investigation November 1942”, 20. The factory was in Birmingham.

${ }^{41}$ DM, March 19, 1941, 1

${ }^{42} D N$, Nov 29, 1941, 3

${ }^{43}$ DT, Feb 1945, 214

${ }^{44} \mathrm{DN}$, Aug 2, 1941, 1

${ }^{45}$ DM, Mar 4, 1942, 5

${ }^{46} \mathrm{DN}$, Apr 18, 1942, 3

${ }^{47} \mathrm{DN}$, Nov 15, 1941, 1

${ }^{48}$ MDD, Sept 1940, 9

${ }^{49} M D D$, Dec 1940, 3

${ }^{50}$ DN, 2 Aug 1941, 4

${ }^{51}$ M-O A FR1105 "Morale in Donnington” Feb 1942, 13-4, 23

${ }^{52}$ DT, Jan 1942, 213

${ }^{53}$ MDD, Apr 1942, 11

${ }^{54}$ Danceland, Sept 1944, 2

${ }^{55}$ Cardiff and Scannell, "Good Luck War Workers"

${ }^{56}$ see Nicholas, "The People's Radio"

${ }^{57}$ J.T. MacCurdy, The Structure of Morale (Cambridge, 1943), 141 cited in McLaine, Ministry of Morale, 8 
${ }^{58} \mathrm{DN}$, Nov $1,1941,1$

${ }^{59}$ Danceland, Aug 1944, 8

${ }^{60}$ Danceland, Oct 1943, 9

${ }^{61} \mathrm{DN}$, Jul 12, 1942

${ }^{62}$ MDD, June 1944, 7

${ }^{63} \mathrm{DN}, \mathrm{Dec} 13,1941,1$

${ }^{64} \mathrm{DN}$, Aug 23, 1941, 1

${ }^{65}$ MDD, Jan 1942, 19

${ }^{66} \mathrm{DN}$, Jul 19, 1941, 1

${ }^{67} \mathrm{DN}$, Aug 30, 1941, 1,

${ }^{68} D N$, Jul 26, 1941, 1

${ }^{69} \mathrm{DN}, \mathrm{Jul} 12,1941,2$

${ }^{70} \mathrm{DN}$, Jul 12, 1941, 2

${ }^{71} \mathrm{DN}, \mathrm{Jul} 26,1941,4$

${ }^{72}$ For further details see Nott, Going to the Palais

${ }^{73} \mathrm{DN}$, Nov 29, 1941, 4

${ }^{74} \mathrm{DN}$, Nov 29, 1941, 4

${ }^{75} \mathrm{DN}$, Aug 2, 1941, 1, 4

${ }^{76}$ DN, Jan 24, 1942, 1

${ }^{77}$ DN, Jan 31, 1942, 1

${ }^{78} \mathrm{DN}, \mathrm{Jan} 31,1942,1$

${ }^{79} \mathrm{DN}$, Jan 31, 1942, 2

${ }^{80} \mathrm{DN}$, Jan $17,1942,2$

${ }^{81}$ DT, Aug 1943, 520

${ }^{82}$ Daily Mail, Oct 5, 1943, 3 
${ }^{83}$ Lichfield Mercury, Jun 2, 1944, 4

${ }^{84}$ Cheltenham Chronicle and Gloucestershire Graphic, Jan 2, 1943, 4

${ }^{85} \mathrm{DN}$, Sept 27, 1941,2

86 “Our Policy - C. L. Heimann,” Weekly Bulletin, No. 163, 1942 in P. Nathan (ed.), CLH says... The collected observations, instructions and philosophies of C. $L$.

Heimann, Joint Chairman, Mecca Ltd. (London, 1963), 24

87 “We Shall Resolve," Weekly Bulletin, No. 260, 1944 in Nathan, CLH, 34

88 "Report of Staff Meeting, June 1941", Weekly Bulletin, No. 116, 1941 in Nathan

CLH, 17

${ }^{89}$ For further details see Nott, Going to the Palais 